Journal of Applied Business, Taxation and Economics Research (JABTER)

Vol. 1, No. 2, 2021 (Page: 205-214)

DOI: $10.54408 /$ jabter.v1i2.31

E-ISSN 2808-263X

\title{
Intellectual Capital and Good Corporate Governance Determinants of Financial Performance
}

\author{
Herman Wijaya ${ }^{1}$, Denny Kurnia ${ }^{2}$, Kodriyah ${ }^{3^{*}}$ \\ University of Serang Raya ${ }^{1,2,3^{*}}$ \\ Corresponding Author: kodriyahunsera@gmail.com ${ }^{3 *}$
}

Keywords : Intellectual Capital, Good Corporate Governance, Company Performance, JII

\begin{abstract}
:
The purpose of this study was to examine the effect of intellectual capital and good corporate governance on company performance. The population in this study were companies listed in the Jakarta Islamic Index during the 2016 - 2019 period. The sampling technique in this study used a purposive sampling technique. This causality research method was analyzed using multiple regression. The data collection method used is the secondary data documentation method, and tested using Partial Least Square (PLS-SEM). The result of this research is that there is an influence between Intellectual Capital on financial performance. The results of corporate governance proxied by the Board of Directors have a significant effect, but the Board of Commissioners and the Audit Committee have no effect on the Company's Financial Performance.
\end{abstract}




\section{Introduction}

The world economy is currently very fast, the industrial revolution 4.0 has changed the view of the business world to be based on knowledge and technology (Knowladge based business) which previously still relied on labor (labor based business). A company needs to assess the level of success of the performance that has been carried out by the company in carrying out its operational activities. The company will report it in the form of financial statements of the financial activities or activities that have been carried out. Financial statements are a tool for management in carrying out the responsibility function and to show the effectiveness of achieving company goals. Information obtained from financial statements is used to establish policies, therefore financial statements are very important for a company.

Several companies included in the calculation of the Jakarta Islamic Index such as Aneka Tambang (Persero), Tbk, PT Indofood Sukses Makmur Tbk., PT Kalbe Farma Tbk. PT Wijaya Karya (Persero) Tbk. In 2018 it has recorded a profit growth of more than 40 percent. PT Indofood Sukses Makmur Tbk. recorded sales and net profit of Rp.73.39 trillion and Rp.4.17 trillion, respectively, in 2018. PT Kalbe Farma Tbk. recorded sales growth of $4.42 \%$ year-on-year (yoy) in 2018, to Rp21.07 trillion from the previous Rp20.18 trillion. PT Wijaya Karya (Persero) Tbk. posted a net profit growth of 43.94 percent on an annual basis in 2018. (Alfi, 2019)

Some researchers reveal that Intellectual Capital has a high tendency to affect the company's financial performance. Intellectual capital is an intangible asset that is often linked in the form of information and knowledge resources which are human resources, because only humans have this thinking power. Therefore, in this study, researchers will review how much intellectual capital contributes to financial performance. .

In addition to science, corporate governance also needs to be applied as a reference in managing the company professionally. With such intense competition, investors will look for companies that are managed professionally by implementing good corporate governance. In several studies on the relationship between corporate governance and financial performance quite a lot has been done, but gives different results because of the differences in the variables used. In this study, researchers conducted research on the mechanism of corporate governance that focused on the internal structure consisting of the composition of the board of directors and commissioners.

Based on the description above, it is known how important intellectual capital and good corporate governance are to support the financial performance of a company, apart from various other factors that affect the company's financial performance. So this study was conducted with the aim of knowing whether there is an influence of Intellectual Capital, and Good Corporate Governance on financial performance 


\section{Research Method}

The research method used in this study is a quantitative research method that processes data and analyzes data using statistical calculation techniques. Based on the characteristics of the form of the problem studied, this type of research is an associative causal research where the research is conducted to prove the causal relationship of several variables. Sugiyono (2017:37) suggests that the associative approach is a research problem formulation that asks for the relationship between two or more variables. Furthermore, causal research is research that is directed to investigate cause-and-effect relationships based on observations of the causal factors through the collected data.

The population in this study are companies indexed in the Jakarta Islamic Index for three periods, namely 2017-2019. The sample selection in this study used a purposive sampling technique with the aim that the selected sample could represent the entire population, where the sample must be based on considerations and have certain criteria to obtain a representative sample of the population. The type of data used in this study is time series data. Time series is data that is chronologically arranged according to time on a certain variable. This study uses time series data for companies listed on the Jakarta Islamic Index. Furthermore, the source of data in this study uses secondary data which refers to information collected from existing sources. According to Sugiyono (2017:137) secondary data sources are data sources that do not directly provide data to data collectors, for example through other people or through documents. The source of data in this study is the Indonesia Stock Exchange which can be accessed through www.idx.co.id.

The relationship among those concepts has to be depicted in a figure of conceptual framework as example below.

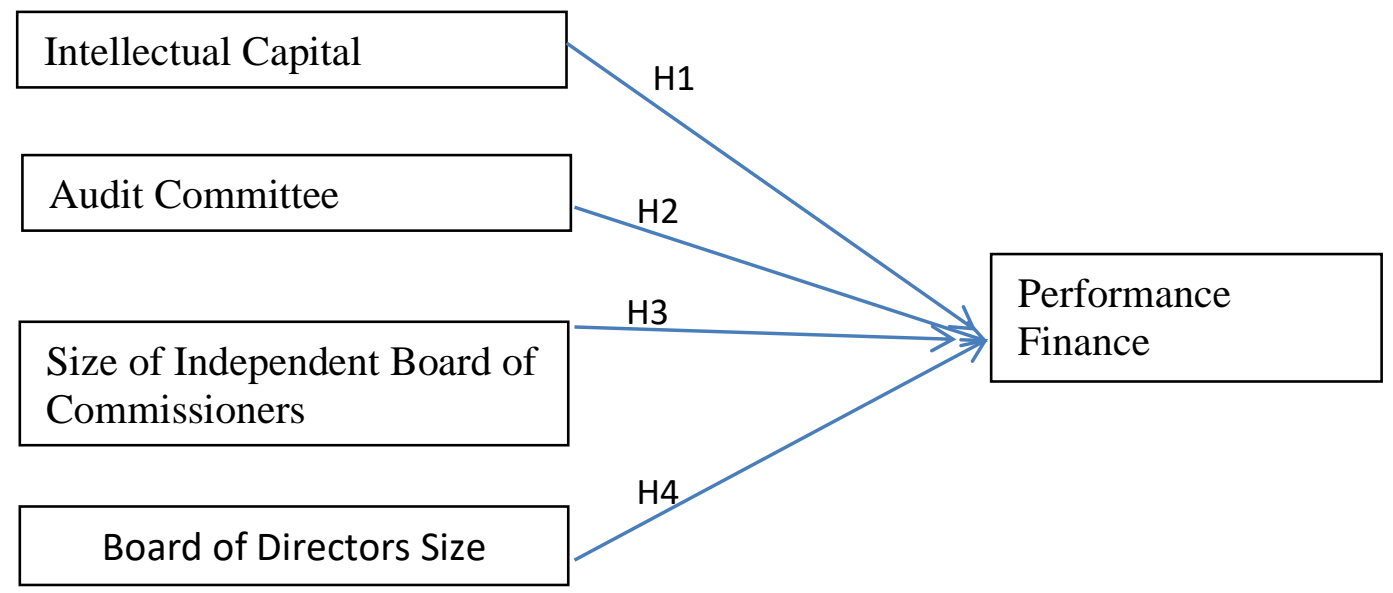

Figure 1. Conceptual Framework 


\section{Results and Discussion}

Companies indexed in the Jakarta Islamic Index consecutively from 2016-2018 are 30 companies each year, but from the total number of companies indexed each year 16 companies are selected that match the research criteria, so the total sample examined is 3 years. years is 48.

Table 1. Descriptive statistics

\begin{tabular}{cllllll}
\hline & Mean & Median & Min & \multicolumn{2}{l}{ Max } & \multicolumn{2}{c}{ Standard Deviation n } \\
\hline Intellectual Capital & 406.667 & 349.000 & 31.000 & 1400.000307 .835 & 48 \\
Audit Committee & 28.542 & 30.000 & 20.000 & 40.000 & 4.077 & 48 \\
Board of Directors Size & 57.292 & 60.000 & 30.000 & 100.000 & 13.653 & 48 \\
Size of Independent Board of Commissioners & 24.792 & 20.000 & 10.000 & 40.000 & 6.767 & 48 \\
ROE & 207.958 & 160.000 & 50.000 & 1090.000187 .447 & 48 & 48 \\
\hline
\end{tabular}

Based on Table 1, all indicators of the dependent and independent variables have a mean value greater than the standard deviation value. This shows that the amount of indicator values between companies has a range that is not far apart.

\section{Assessing the Outer Model (Measurement Model)}

Outer model is a model that specifies the relationship between the latent variable and its indicators or it can be said that the outer model defines how each indicator relates to the latent variable. Outer model for convergent value (convergent validity), discriminant value (discriminant validity), composite reliability, Average Variance Extracted (AVE) and Cronbach's alpha. The PLS Algorithm model is presented The PLS Algorithm model is presented in the image below this.

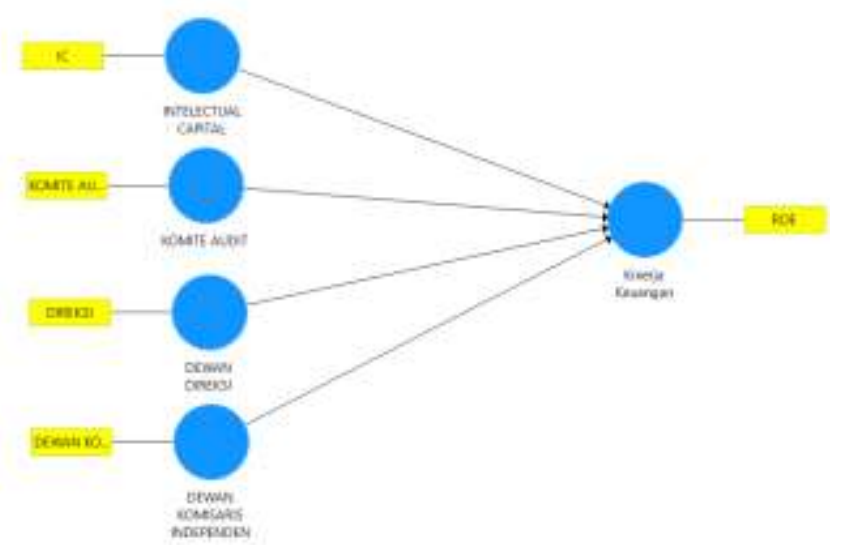

Figure 2. PLS Algorithm Model 
The measurement model is carried out to test the relationship (loading value) between the indicator and the construct (latent variable). For the Convergent validity of the measurement model with reflexive indicators, it is assessed based on the correlation between the item scores/component scores estimated with the SmartPLS software. Individual reflexive measures are said to be high if they correlate more than 0.7 with the construct (latent variable) being measured. However, according to Chin (in Ghozali 2006), for research in the early stages of development, a loading value measurement scale of 0.5 to 0.6 is considered sufficient.

\section{Convergent Validity}

The convergent value is to measure the loading factor for each latent variable. A loading factor above 0.70 is highly recommended, however, a loading factor above 0.60 can still be tolerated as long as the model is still in the development stage. Of all the variables, the loading value is 1 , this means that all indicators are valid as a measure of the construct.

Discriminant validity.

The discriminant value is useful for assessing whether the variable has adequate discriminant validity, namely by comparing the correlation of the indicator with the intended construct, which must be greater than the correlation with other constructs. If the indicator correlation has a higher value than the indicator correlation with other constructs, it is said that the variable has high discriminant validity. This value can be seen in the value of the cross loading factor. The results of the complete cross loading value are as follows:

Table 2. Discriminant Validity

\begin{tabular}{lccccc}
\hline & $\begin{array}{c}\text { BOARD OF } \\
\text { COMMISSIONERS }\end{array}$ & $\begin{array}{c}\text { BOARD OF } \\
\text { DIRECTORS }\end{array}$ & $\begin{array}{c}\text { INTELECTUAL } \\
\text { CAPITAL_ }\end{array}$ & $\begin{array}{c}\text { FINANCIAL } \\
\text { PERFORMANCE }\end{array}$ & $\begin{array}{c}\text { AUDIT } \\
\text { COMMITTEE }\end{array}$ \\
\hline $\begin{array}{l}\text { INDEPENDENT } \\
\text { BOARD OF } \\
\text { COMMISSIONERS }\end{array}$ & 1,000 & 0.479 & -0.133 & -0.008 & 0.027 \\
$\begin{array}{l}\text { BOARD OF } \\
\text { DIRECTORS }\end{array}$ & 0.479 & 1,000 & -0.075 & -0.392 & 0.116 \\
$\begin{array}{l}\text { INTELLECTUAL } \\
\text { CAPITAL }\end{array}$ & -0.133 & -0.075 & 1,000 & -0.174 & 0.283 \\
$\begin{array}{l}\text { AUDIT } \\
\text { COMMITTEE }\end{array}$ & 0.027 & 0.116 & 0.283 & -0.061 & 1,000 \\
ROE & -0.008 & -0.392 & -0.174 & 1,000 & -0.061 \\
\hline
\end{tabular}

In the table above, it can be seen that the loading indicator value of the Board of Independent Commissioners is 1,000 higher than other constructs, namely to the directors of 0.479, Intellectual capital -0.133, Financial performance -0.008 and the Audit Committee 0.027. Likewise for loading the Board of Directors Indicators. Against the Board of Commissioners' 
construct 0.479, Intellectual capital -0.075, Financial Performance -0.392 and Audit Committee 0.116. Likewise, Variable IC, Audit Committee, and ROE, have a higher loading value to the targeted block compared to other blocks.

Composite Reliability

A high composite reliability value indicates a good consistency of each indicator in the latent variable to measure the variable. The criterion of composite reliability value $>0.7$ indicates that the variable has good internal consistency. The complete composite reliability value is presented in the table below.

Table 3. Composite Reliability Value

\begin{tabular}{lc}
\hline & Composite Reliability \\
\hline BOARD OF COMMISSIONERS & 1,000 \\
BOARD OF DIRECTORS & 1,000 \\
INTELLECTUAL CAPITAL & 1,000 \\
FINANCIAL PERFORMANCE & 1,000 \\
AUDIT COMMITTEE & 1,000 \\
\hline
\end{tabular}

The table above shows that the composite reliability value of the Overall Variable is 1 , all of these constructs have a composite reliability value of $>0.70$, so it is said to have good internal consistency.

\section{Average Variance Extracted (AVE)}

The AVE value shows the variance value for each indicator in the construct that can be captured by these variables more than the variance caused by measurement errors. Expected AVE value $>0.5$. The AVE value of the overall construct of the variable is 1 ,

Table 4. Average Variance Extracted

\begin{tabular}{lc}
\hline & $\begin{array}{c}\text { Average Variance } \\
\text { Extracted (AVE) }\end{array}$ \\
\hline BOARD OF COMMISSIONERS & 1,000 \\
BOARD OF DIRECTORS & 1,000 \\
INTELLECTUAL CAPITAL & 1,000 \\
FINANCIAL PERFORMANCE & 1,000 \\
AUDIT COMMITTEE & 1,000 \\
\hline
\end{tabular}

\section{Cronbach's Alpha}

The reliability test was strengthened by Cronbach's alpha value. Cronbach's alpha reliability test limits $>0.7$. The value of Cronbach's alpha obtained by the overall variable 
construct is 1 . The results of the complete Cronbach's alpha value are presented in the table below.

Table 5. Cronbach's Alpha . value

\begin{tabular}{lc}
\hline & Cronbach's Alpha \\
\hline BOARD OF COMMISSIONERS & 1,000 \\
BOARD OF DIRECTORS & 1,000 \\
INTELLECTUAL CAPITAL & 1,000 \\
FINANCIAL PERFORMANCE & 1,000 \\
AUDIT COMMITTEE & 1,000 \\
\hline
\end{tabular}

Structural Model Test (Inner Model)

To test the structural model, it is done by looking at the value of R2 which is the Goodness of the fit test. The Financial Performance Contract obtained an R2 value of 0.231 which can be interpreted that the variance in Financial Performance can be explained by the Intelcetual capital, Board of Commissioners, Board of Directors, Audit Committee constructs of $23 \%$ while the remaining $77 \%$ is explained by other variables outside the studied. The complete R2 value results are presented in the table below.

Table 6. R-Square Nilai Value

\begin{tabular}{rr}
\hline construct & R Square \\
FINANCIAL PERFORMANCE & 0.231 \\
\hline
\end{tabular}

The next test is to see the significance of the influence between independent constructs on the dependent and answer what has been hypothesized. Testing with a significance level of $5 \%$ if the t-statistic value $>1.68$ then the null hypothesis $(\mathrm{HO})$ is rejected. The t-statistic value of the influence coefficient of the latent construct was obtained from PLS Bootstrapping. The results of the PLS Bootstrapping Model are presented in the image below.

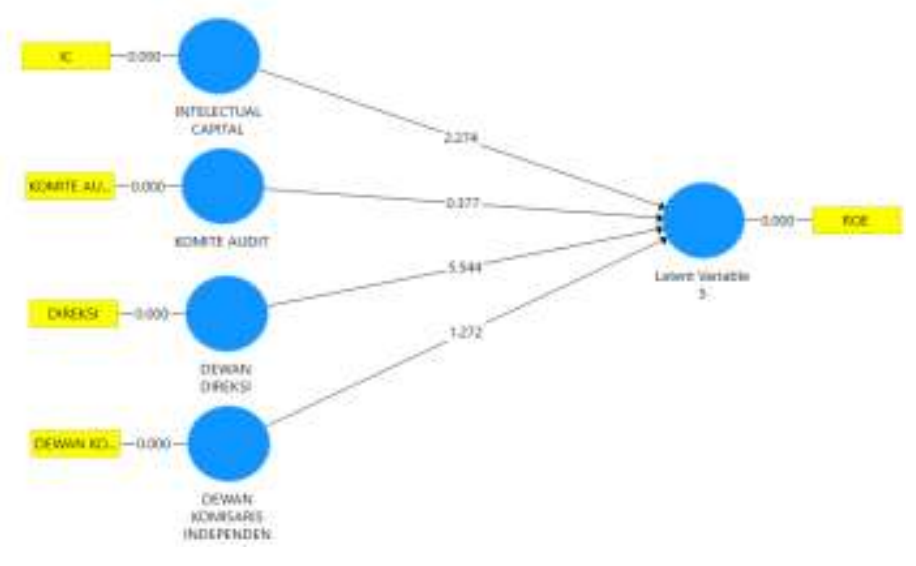

Figure 3. PLS Bootstrapping Model 
The parameter coefficient values can be seen in the value (original sample) and the t-statistical significance value can be seen in the table below.

Table 7. Coefficient Value (Original Sample), Standard Error and T-Statistics and p-values

\begin{tabular}{|c|c|c|c|c|c|}
\hline CONTRACT & $\begin{array}{l}\text { Original } \\
\text { Sample } \\
\text { (O) }\end{array}$ & $\begin{array}{c}\text { Sample } \\
\text { Mean (M) }\end{array}$ & $\begin{array}{c}\text { Standard } \\
\text { Deviation } \\
\text { (STDEV) }\end{array}$ & $\begin{array}{c}\text { T Statistics } \\
(|\mathrm{O} / \mathrm{STDEV}|)\end{array}$ & P Values \\
\hline \multicolumn{6}{|l|}{ BOARD OF DIRECTORS -> } \\
\hline FINANCIAL & -0.513 & -0.548 & 0.093 & 5.544 & 0.000 \\
\hline \multicolumn{6}{|l|}{ PERFORMANCE } \\
\hline \multicolumn{6}{|l|}{ INDEPENDENT BOARD OF } \\
\hline $\begin{array}{l}\text { COMMISSIONERS -> } \\
\text { FINANCIAL }\end{array}$ & 0.210 & 0.247 & 0.165 & 1,272 & 0.204 \\
\hline \multicolumn{6}{|l|}{ PERFORMANCE } \\
\hline \multicolumn{6}{|l|}{ INTELECTUAL CAPITAL -> } \\
\hline FINANCIAL & -0.199 & -0.200 & 0.087 & 2,274 & 0.023 \\
\hline \multicolumn{6}{|l|}{ PERFORMANCE } \\
\hline \multicolumn{6}{|l|}{ AUDIT COMMITTEE -> } \\
\hline FINANCIAL & 0.049 & 0.047 & 0.130 & 0.377 & 0.707 \\
\hline PERFORMANCE & & & & & \\
\hline
\end{tabular}

\section{Conclusion}

Based on data analysis, it was found that Intellectual Capital has a significant positive effect on the company's performance, this indicates that if the company can manage and develop its intellectual capital well, there will be an increase in ROA which indicates better financial performance, resulting in a competitive advantage for the company. . On the basis of competitive advantage and added value, the company gets more awards from investors by investing more in the company. The higher the intellectual capital, the higher the company's financial performance, so that the competitive advantage and added value obtained can improve the company's financial performance. This is in line with research conducted by (Chen et al., 2005) and (Ulum, 2009)shows that intellectual capital has a positive effect on company profitability. Therefore, intellectual capital has an effect on financial performance.

Based on the data analysis conducted, it shows that the audit committee has a negative effect on financial performance. The audit committee as a form of supervision carried out by the company turns out to be incapable of existenceimprove the quality of the company's internal supervision, and cannot optimize checks and balances which in the end cannot provide protection to the same holders and stakeholders, resulting in the company's performance not being able to run properly.

The results of this study can occur because the more the number of audit committees, the more control and supervision will be carried out, this will take into account many decisions 
from the audit committee that come from different educations. This is in line with research This study is in line with previous research conducted by Bouaine \& Hrichi (2019) and Ferial et al. (2016) which says that the audit committee has a negative effect on financial performance. andAmelia ( 2019 ).

From the results of testing and data analysis, it is found that the size of the board of commissioners has a negative effect on company performance. The results of this study can occur because the greater the proportion of independent commissioners in the company, the supervision carried out by independent commissioners will minimize management actions that only think about the interests of the company and reduce fraudulent actions that can harm the company. However, in fact, the proportion of independent commissioners does not make a positive contribution to financial performance, which means that the size of the proportion of independent commissioners cannot guarantee good oversight, management, and accurate decision-making functions within a company (Azis \& Hartono, 2017).

The theoretical implication of the results of this study is that the research results are not in line with agency theory, which states that based on the agency relationship in Agency theory, an independent board of commissioners is assigned as an agent by the principal to manage the company in order to increase the principal's return and welfare. It is hoped that the results of this study can contribute to the results of the study which states that the independent board of commissioners has no effect on financial performance as proxied by ROA.

Test results The size of the board of directors on the company's performance, is able to provide significant positive results on the company's performance. The board of directors has a very vital role in a company. With the separation of roles from the board of commissioners, the board of directors has great power in managing all the resources in the company. The board of directors has the task of determining the direction of policy and resource strategies owned by the company, both for the short and long term. The size of the board of directors is one of the very important Corporate Governance mechanisms in determining the company's performance. This is in line with Panky's research (2014)

\section{References}

Chen, M. C., Cheng, S. J., \& Hwang, Y. (2005). An empirical investigation of the relationship between intellectual capital and firms' market value and financial performance. Journal of Intellectual Capital, 6(2), 159-176. https://doi.org/10.1108/14691930510592771

El-chaarani, H. (2014). The impact of corporate governance on the performance of lebanese banks. 8(5), 35-46.

Fahmi, I. (2011). Analisis Laporan Keuangan (1st ed.). Alfabeta.

Ghozali, I. 2013. Aplikasi Analisis Mulvariate dengan Program IBM SPSS 21. Semarang: Universitas Diponegoro. 
Hadi, N., \& Arifin, S. (2002). Analisa Faktor - Faktor yang mempengaruhi luas pengungkapan sukarela dalam laporan tahunan perusahaan go Publik di BEJ. Jurnal Maksi 1, 1, 90-105.

Hamdani. (2016). Good governance Perusahaan bisnis Sumber daya manusia Organisasi Manajemen organisasi Etika bisnis Moral karyawan Good corporate governance Etika. Mitra Wacana Media.

Hatane, Adrian Gozali, S. E. (2013). Pengaruh Intellectual Capital Terhadap Kinerja Keuangan Dan Nilai Perusahaan Khususnya Di Industri Keuangan Dan Industri Pertambangan Yang Terdaftar Di Bursa Efek Indonesia Tahun 2008 - 2012. Journal of Chemical Information and Modeling, 53(9), 1689-1699.

Muhamad. (2014). Manajemen Keuangan Syariah. UPP STIM YKPN.

Pandya, H. (2011). Corporate Governance Structures and Financial Performance of Selected Indian Banks. 2(2), 4-22.

Pratiwi, T. R. (2017). Pengaruh Intellectual Capital dan Corporate Governance Terhadap Kinerja Keuangan Perbankan di Indonesia. Jurnal Akuntansi Dan Keuangan, 8(1). https://doi.org/10.36448/jak.v8i1.827

Ratnasari, R. B., Titisari, K. H., \& Suhendro. (2016). Pengaruh Value Added Intellectual Capital, Gcg, Dan Struktur Kepemilikan Terhadap Kinerja Keuangan. Journal of Economic and Economic Education, 4(2), 240-257.

Sangkala. (2006). Intellectual capital management: strategi baru membangun daya saing perusahaan. Yapensi.

Soegeng, S., \& Safrina, M. (2014). Pengaruh Intellectual Capital terhadap Kinerja Keuangan pada Perusahaan Perbankan. SNA XVII Mataram.

Supriatna, N., \& M. Kusuma, A. (2009). Pengaruh Good Corporate Governance Terhadap Kinerja Perusahaan. Jurnal ASET (Akuntansi Riset), $1(1), \quad 1$. https://doi.org/10.17509/jaset.v1i1.8907

Ulum, I. (2009). Intellectual Capital: Konsep dan Kajian Empiris. 